\title{
Dictogloss for English Language Teaching: An Experimental Lesson and Reflections
}

\author{
Jayaron Jose \\ English Language Centre, University of Technology and Applied Sciences \\ Al Musanna, PO Box 191, PC 314, Oman \\ Tel: 968-9-213-2495Ｅ-mail: jayaronjose@gmail.com \\ Received: January 29, 2022 Accepted: February 21, 2022 Published: February 27, 2022 \\ URL: https://doi.org/10.5296/ijl.v14i1.19605
}

doi:10.5296/ijl.v14i1.19605

\begin{abstract}
While ELT emphasizes on well-known teaching approaches such as PPP (Presentation, Production and Practice) or Test-Teach-Test (TTT) for planning and implementing lessons, most EFL professionals rarely experiment with approaches such as Dictogloss, Silent Way, TBLT (Task Based Language Teaching), and so on. While an eclectic approach to teaching English can help achieve lesson aims better, deeper insights into specific approaches can sharpen teachers' professional edge. Dictogloss, therefore, is one of such approaches that integrates all skills in planning and delivering ELT lessons. The researchers' experiment with the approach of dictogloss and reflections are summarized in this article. The report includes the need for using dictogloss approach in ELT, a brief literature review, objectives of the experimental lesson, methodology, findings and analysis, recommendations, and conclusion. Overall, this qualitative study on the experimental dictogloss lesson and its reflections concluded at a positive note.
\end{abstract}

Keywords: Dictogloss, Experimental lesson, Reflections

\section{Introduction}

Most ELT lessons are focused on either one or two skills, lexical or system items exploiting traditional communicative methodology and teaching approaches as PPP or TTT. However, this comparatively newer teaching approach of dictogloss provides ELT professionals an opportunity for integrating four skills and systems in a lesson. Often, due to a number of reasons, teachers could not effectively integrate all four skills in lessons, but the method of dictogloss provides teachers and learners the opportunity integrate skills particularly to write in English with an increased grammatical accuracy (Kurtaj, 2021) along with listening, speaking, and reading. 
Dictogloss, therefore, is a method that enables ELT practitioners to integrate all four skills and the language into one lesson effectively giving them a chance to carry out a learner centred lesson, and learners an occasion to work in groups and pairs interchangeably. All these features of dictogloss help professionals to reduce teacher-centeredness in lessons. While dictogloss enables learners to collaborate with their peers through peer teaching and peer-corrections, this also helps teachers reduce teacher-talk-time. In addition, despite its easier preparation, dictogloss opens opportunity for FFL/ESL teachers to give effective feedback to learners extensively and naturally building on their input.

\section{Literature Review}

Dictogloss is a classroom dictation activity where learners reconstruct a text after listening to it and noting down its key words (Tsauri, 2021; "Dictogloss", n.d.). This method was initiated in 1990 by Ruth Wajnryb to teach grammar through dictating, paraphrasing and interpreting target text engaging learners with multiple skills (Kurtaj, 2021). Puspita (2016) defines dictogloss is a multiple skills activity where learners engage in listening, speaking, reading and writing relying on their 'knowledge of semantic, syntactic and discourse systems of the target language' (p.175) with note taking skill as a by-product. While studies by Tsauri (2021) and Muthmainnah, Asrifan, Al Yakin, and Sahabuddin, (2019) found that this method enhances learner's listening skills, Chun (2021) found that dictogloss can be modified for genre-based writing instructions.

Further, dictogloss is a type of information gap because it creates real need for learners to communicate to collect and negotiate information among peers to bridge the gap for completing tasks (Wajnryb, 1990). In the process, learners negotiate meaning, notice errors and repair them. So, it is not about writing the original text, but the learning process of producing text that is closest to the meaning, content, and function of the original one (Fong \& Idek, 2015). The dictation texts can be short excerpts from newspapers, academic texts, stories or teacher-prepared ones with some transactional aims (Vasiljevic, 2010).

\subsection{Stages of Dictogloss}

Dictogloss lesson follows certain stages - one built on the other in each lesson. Wajranb (1990) suggested four stages of dictogloss as detailed below.

\subsubsection{Preparation}

At this stage, teachers explain the dictogloss methodology of the lesson and pre-teach some vocabulary or new words in preparation for the dictation stage. Moreover, learners, especially the lower level ones, can be instructed to write only content words during listening; however, higher level learners need to write down every word (function and content) that they hear (Oxenden, 2014). Teachers can divide learners into pairs and group at this stage.

\subsubsection{Dictation}

Learners hear the text twice. First time, teachers read the text at a normal speed and learners just listen to get the general idea of the text without taking any notes. In the second dictation, learners take notes while listening. Teachers should make sure to dictate a semantic unit of 
one sentence at a time. At the start of second dictation, teachers can remind learners whether to write all words or only content words.

\subsubsection{Reconstruction}

At this stage, learners in groups pool their notes and information to reconstruct their version of original text that they heard. One group leader, the scribe, write down the text listening to peers. Then the notes are interchanged between groups to check grammar, textual cohesion, and coherence.

\subsubsection{Analysis and Correction}

At this stage, one representative from each group, taking turns, reads out the text openly, and they compare their texts. Then learners discuss and correct errors. The matching or comparison of the texts can be done in different ways (e.g., manually exchanging drafts) to make sure that errors are corrected, and hypothesis are checked.

\subsection{Learners' Level and Dictation}

Dictogloss method can be used across all levels, and teachers should be considerate about learners' level when the listening content is selected in terms of difficulty level and learning challenges. Thornburry (1999) and Wajnaryb (1990) do not specify the level of learners, but they emphasis on the integrated skills and language items such as words, phrases, or sentences in dictogloss lessons.

The initial studies (Wajnaryb, 1990; Kurtaj, 2021) mentioned teachers' reading aloud at the dictation stage of the lesson; whereas Tri (2019) and Wahyuningsih (2019) mention that either teachers themselves can read, record their voice, or select suitable pre-recorded audios for dictogloss. The researcher thinks it would be better to select short authentic audios for implementing dictogloss lesson exposing learners to real-life use of English language.

\subsection{Merits of Dictogloss}

Different merits of using dictogloss in classrooms based various sources (Dewi, 2017; Kurtaj, 2021; "The advantages", 2015; Wajnryb, 1990) of the researcher's reading are listed below.

\subsubsection{Collaborative Learning Activities}

Students listen to teachers individually and take down notes; then they compare their notes in pairs and work in groups for reconstruction. This collaborative learning enhances their social and interpersonal skills.

\subsubsection{Development of Communicative Competence}

Dictogloss is different from conventional discussions where learners ask and answer given questions, but they interact in groups naturally using all modes of authentic communication such as more turn-taking, and using strategies for confirmation and clarification.

\subsubsection{Learners' Identifying Strengths and Weaknesses}

The reconstruction stage helps learners to identify their strengths and weaknesses affectively 
and cognitively. It is a time for them to listen to their peers, interact with them, recall what they have heard, note down, and write them in paragraphs or long text. In the process, they can know the areas of their strength and weaknesses for future improvement.

\subsubsection{Awareness of Rhetorical Patterns}

The reconstruction stage in dictogloss helps learners' identity patterns of textual organization and the use of cohesive devices such as discourse markers. Consequently, they would realize that coherence and cohesion are integral part of writing a text, and work toward improving them.

\subsubsection{Learning in Context}

Learners learn language items especially grammar in context during the reconstruction stage with the help of their notes, existing knowledge, and opinions about the known topic. This presents them with a meaningful and purposeful learning experience.

\subsubsection{Motivating}

Dictogloss motivates learners because it engages them in collaborative activities. Also, the error correction stage after the reconstruction exploits learners' strong desire to know how their work match with the original one, and it excites them, too. Learners feel the need for correction and feedback after the reconstruction stage as a source of motivation.

\subsubsection{Experiential Learning}

Learners use language experientially during the reconstruction stage helping them apply their knowledge immediately as in real-life. Here, learners do not use some words or phrases taught by teachers, but they use their own existing language to discuss ideas and construct a text collaboratively as in real-life, and this improves their self-confidence and leadership skills with a feeling of community belongingness.

\subsubsection{Creative Learning}

In the reconstruction stage learners do not write an exact copy of the original text, but a text of their own referring to their gathered notes and peer feedback. This ensures that learners have to write a draft of their own creatively adding their thoughts and words, which may be slightly different from the original text.

\subsubsection{Assessment}

Teachers can assess or test learners' knowledge while teaching and give them appropriate feedback after the reconstruction stage. The reconstruction stage is the time when teachers can observe and note down learner errors for common feedback during the analysis and error correction stage.

\subsection{Some Possible Drawbacks}

Some areas that are to be cautious of dictogloss is that some students may be shy, and they may not actively participate in discussions due to their cultural influence. For example, some 
Japanese learners are hesitant to speak openly to express themselves (Vasiljevic, 2010), and they find it comfortable to work among themselves. A similar pattern of behaviour was found among some Arab learners of English at the researcher's workplace too. This may negatively affect the group dynamics. In addition, to implement dictogloss effectively balancing all skills in a single lesson may be challenging due to the time factor. It may take longer time (Ibid.) to check and give feedback to learner errors especially during correction and feedback session. In addition, the researcher thinks learners who are used to PPP (Present, Practice, Produce) and TTT (Test Teach Test) approaches of learning giving emphasis on one or two skill, lexis or system may not find dictogloss as an appropriate method for lessons. So, creating learner awareness about rationale of this approach is important before implementing it in lessons.

\section{Objectives of Experimental Dictogloss Lesson}

Based on the researchers' reading and studies, he decided to experiment a dictogloss lesson (Appendix A) with his adult pre-intermediate level learners with the following aims.

To discover if

i. dictogloss method is effective with the adult pre-intermediate level learners.

ii. this method helps students identify their strengths and weaknesses.

iii. students can reconstruct the text by only listening to it.

iv. students collaborate with each other in the reconstruction stage.

v. students are motivated to engage themselves with a dictogloss lesson.

vi. students are actively engaged with four language skills.

vii. the researcher could follow all the stages in implementing the lesson.

viii. the teaching materials and listening audio are appropriate.

ix. the researcher could continue using this method in future.

\section{Methodology}

Based on the objectives (3), and the literature review, a lesson following dictogloss method was designed for pre-intermediate adult learners. The experiment mostly followed a qualitative method of collecting data from co-teachers, and students in addition to the researcher's reflections and observations. A questionnaire was prepared for students and teachers to get their perception on the lesson to cross check them with the researcher's reflections. In brief, the experimental lesson (EP) was evaluated based on 1) the researcher's self-evaluation (Appendix B), 2) students' feedback and co-teachers' feedback (Appendices C and $\mathrm{D}$ respectively). Meanwhile, the following section summarizes findings and their analysis. 


\section{Findings and Analysis}

The self-evaluation and the observation helped the researcher know that all stages progressed smoothly, and the pre-intermediate adult learners participated actively in the lesson especially at the reconstruction stage (Appendix A), enabling them write two paragraphs, read and compare their writing output with the original text achieving the lesson aim.

Moreover, learners' feedback (Appendix C) immediately after the lesson conveyed that they liked the lesson, and they thought that it the lesson met their learning needs satisfactorily. Further, they felt dictogloss could improve their listening skill and speaking skill over writing and reading skills in the order of importance, and they felt dictation stage was the most interesting followed by the reconstruction and the analysis stages.

In addition, teachers' feedback (Appendix D) informed the researcher that they also felt dictogloss was good for meeting learners' needs, and all of them had a positive opinion about the method. Moreover, they observed that it was better for improving learners' listening, speaking, reading, and writing skills. However, the absence of effective teaching on focused areas was observed by the teachers.

Overall, the triangulation of all these data has convinced the researcher that dictogloss is appreciated by both learners and teachers, and it can be used to facilitate language teaching and learning in an integrated framework of all four skills. The learners felt that dictogloss lesson could help them identify their weak areas of learning while co-teachers had a mixed opinion. Both co-teachers and learners did not find the lesson helpful in grammar and vocabulary; it was probably because there was no focused teaching on these. Furthermore, leaners were motivated, and they collaborated well in the lesson. Finally, the easiness of preparation and the delivery is an important advantage of this method, and teachers and learners strongly agreed that they would like to use dictogloss in the future. Overall, the experiment mostly agreed with the findings of previous studies (Chun \& Aubrey, 2021; Muthmainnah, e.al., 2021; Tsauri, 2021).

\section{Recommendations and Conclusion}

The experimental dictogloss lesson was conducted for pre-intermediate level adult learners from different countries, but it would be better to try this with learners from other cultural backgrounds at different levels and ages. For example, taking a dictogloss lesson for Arab pre-intermediate or intermediate level learners in the Middle East can help stakeholders understand how they respond to this approach. This approach of dictogloss compared to other approaches can be carried forward as a research topic among different future batches of EFL learners followed by presentation and publication of their findings on different national and international platforms. Furthermore, stakeholders can conduct workshops or training on this at Language Centers enlightening those teachers who are not used to the idea of dictogloss and other approaches, and sharing ideas with those ones who are more experienced with different approaches to language teaching and learning. Regarding language focus, teachers can focus on certain areas or sub-skills such as grammar, vocabulary, genre, coherence, cohesion or word forms based on learners' needs while planning and implementing a 


\section{Macrothink}

dictogloss lesson.

In addition, the researcher thinks teachers can include this technique as part of their regular lessons at times because each lesson last for $100 \mathrm{~min}$, and learners and teachers may feel a bit monotonous with PPT and TTT approaches. Also, dictogloss principles can be exploited with shorter texts as a change or filler in some lessons, and some selected lessons at intervals may be dedicated for a full-fledged dictogloss method of instruction.

\section{References}

Chun, L. T., \& Aubrey, S. (2021). Using a Modified Dictogloss to Improve English as a Second Language Learners' use of Genre-appropriate Conventions and Style. RELC Journal, 00336882211045783.

Dewi, E. M. (2017). Improving Students' Grammar Using Dictogloss. English Education Journal (EEJ), 8(3), 352-366.

$\begin{array}{llll}\text { Dictogloss. } & \text { (n.d.). Dictogloss. } & \text { Retrieved }\end{array}$ https://www.teachingenglish.org.uk/article/dictogloss

Fong L. L., \& Idek, S. (2015). The Use of Dictogloss as an Information Gap Task in Exploiting Dual Application Principle in Learning Irregular Verbs. Journal of Management Research, 7(2). Retrieved from https://www.macrothink.org/journal/index.php/jmr/article/view/6987

Kurtaj, S. (2021). The Use of Dictogloss Technique in Teaching Grammar Through Writing. European Journal of Language and Literature, 7(2), 84-90.

Muthmainnah, M., Asrifan, A., Al Yakin, A., \& Sahabuddin, C. (2019). The use of dictogloss technique on ELT classroom: An experiment study of students listening comprehension. In Proceedings of the 65th TEFLIN International Conference (Vol. 65, No. 01).

Oxenden, C. (2014). English File 3rd Edition Upper Pre-intermediate: Dictogloss (video). Retrieved from https://www.youtube.com/watch?v=av7EJPvbU8c

Puspita, N. (2016). Enhancing students' Listening Skills through Dictogloss. Journal Tadris Bahasa Inggris, 9(1), 173-185.

The advantages'. (2015). The Advantages of Dictogloss Technique. Retrieved from http://hariku23.blogspot.com/2015/01/the-advantages-of-dictogloss-technique.html

Thornbury, S. (1999). How to Teach Grammar. London: Longman.

Tri, B. S. (2019). How to Teach Listening In Senior High School. IJoEFL 1(1), $42-48$

Tsauri, S. S. (2021). The Effect of Dictogloss on Students' Listening Achievement. Journal PAJAR (Pendidikan Dan Pengajaran), 5(2), 262-269.

Vasiljevic, Z. (2010). Dictogloss as an Interactive Method of Teaching Listening Comprehension to L2 Learners. English Language Teaching, 3(1). 


\section{Macrothink}

International Journal of Linguistics

ISSN 1948-5425 2022, Vol. 14, No. 1

Wahyuningsih, R. (2019). The Effectiveness of Dictogloss Technique on Listening Skill of Short Functional Text at the Eight Grade Students of MTSN 2 MADIUM. Retrieved August 8, 2021, from http://etheses.iainponorogo.ac.id/6924/1/RAHAYU\%20WAHYUNINGSIH.pdf

Wajnryb, R. (1990). Grammar dictation. Oxford, England: Oxford University Press.

\section{Appendix A. Experimental Lesson Plan/ Dictogloss}

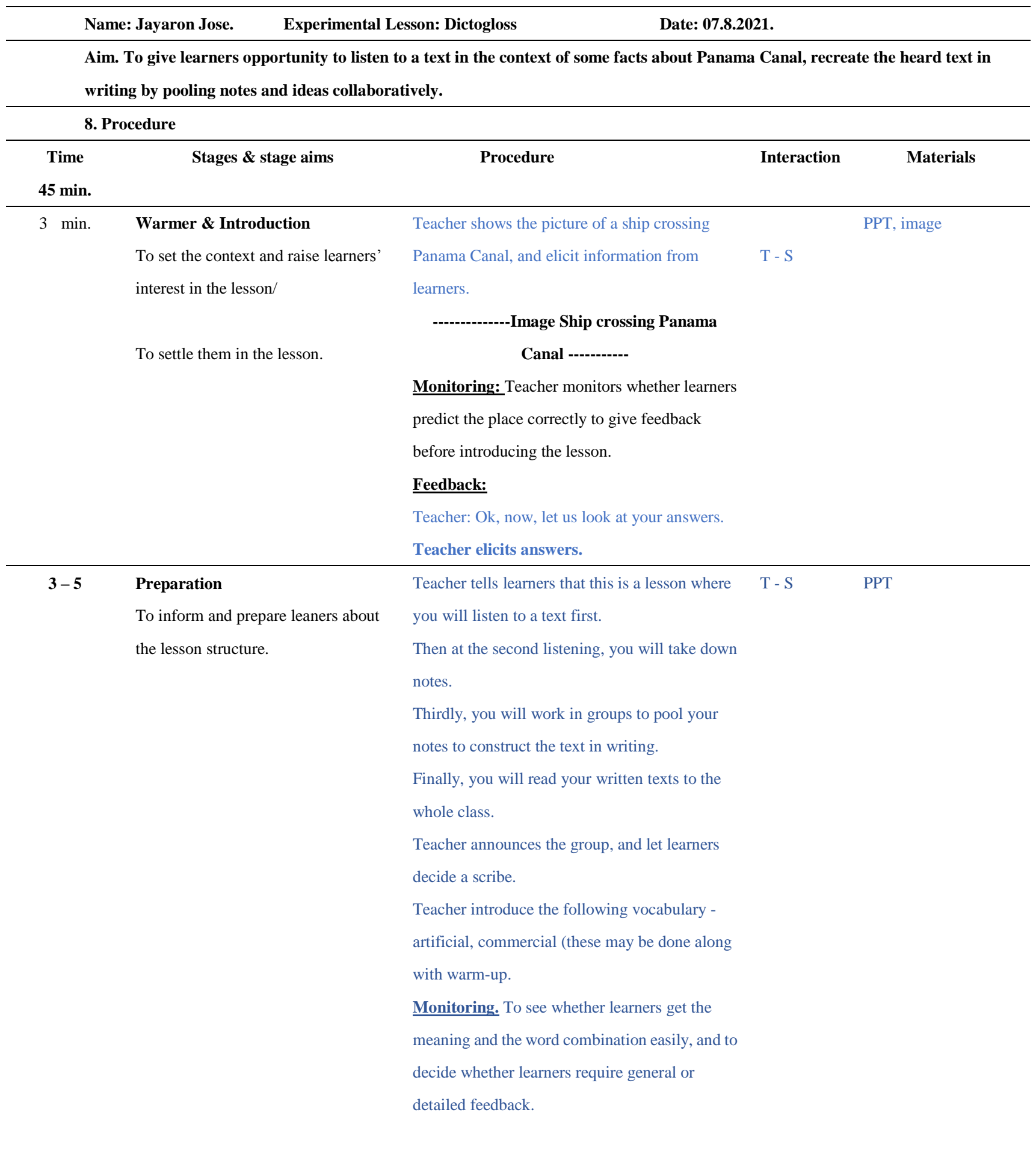


Dictation - Second listening

To listen for details and take notes

To prepare leaners for collaboration in the next stage.
Learners listen to the audio again and take notes.

Monitoring: To check whether all of them are

taking notes - either electronically or manually.
Audio (LP Appendix

1)

https://learnenglish.bri tishcouncil.org/skills/li stening/pre-pre-interm ediate-a2/facts-and-fig $\underline{\text { ures }}$

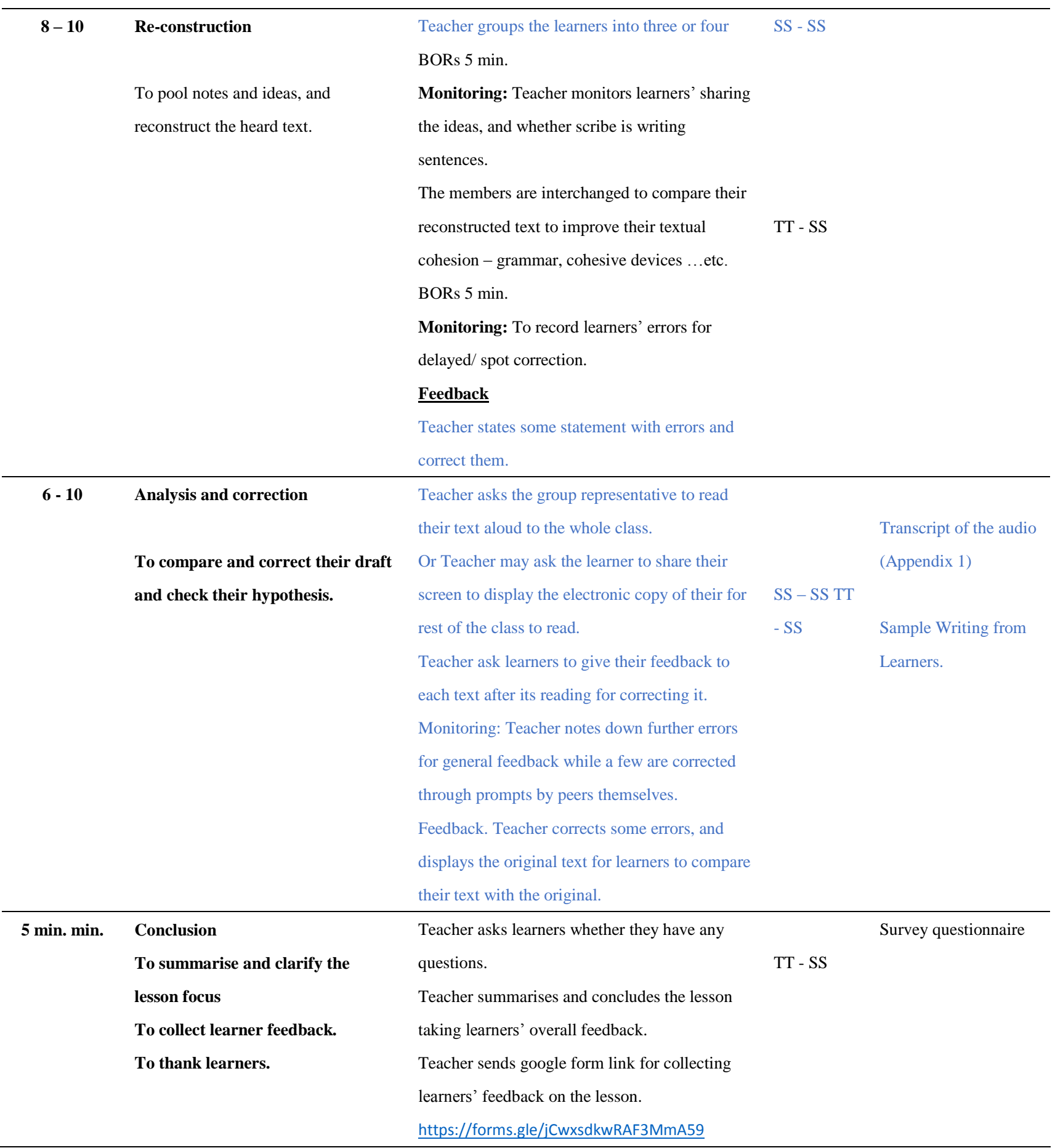




\section{Appendix B. Post Lesson Self-Evaluation/ Reflection on the Lesson}

\section{Overall comment}

The lesson was aimed at making pre-pre-intermediate adult learners giving them opportunity to listen to a text in the context of some facts about Panama Canal, recreate the heard text in writing by pooling notes and ideas collaboratively.

\section{Planning}

Key strengths

1. Stages. The four dictogloss lesson stages (preparation, dictation, reconstruction and analysis and feedback).

2. Setting the context of Panama Canal.

\section{Key weaknesses}

1. The feedback after reconstruction.

2. Timing for stage -4 - Analysis and feedback

\section{How did this impact on learners' progress in the \\ lesson?}

1. This enabled learners to follow the lesson building their learning progressively from one stage to another.

2. This raised learners' interest and helped them do the task meaningfully and purposefully

\section{How did this impact on learners' progress in the lesson? Suggested improvements.}

1. Learner could not get enough feedback on grammatical features of their writing except for the content. This is to be followed up in the next lesson.

2. The planned time for reconstruction and feedback was only $10 \mathrm{~min}$. They took almost $8 \mathrm{~min}$. for reconstruction, and the remaining time was insufficient for a detailed feedback. Need to allocate realistic time to achieve each lesson stage.

\section{Teaching}

\begin{tabular}{|c|c|}
\hline Key strengths & Key weaknesses \\
\hline $\begin{array}{l}\text { 1. Learner interaction. There was sufficient BOR } \\
\text { time for learner discussion. }\end{array}$ & $\begin{array}{l}\text { 1. Less teaching. I could have used more time for } \\
\text { teaching at stage }\end{array}$ \\
\hline 2. Learners' Note taking. & $\begin{array}{l}\text { 2. Instructions on taking notes. I could have } \\
\text { instructed both the groups to type their answers on a } \\
\text { word processor. }\end{array}$ \\
\hline $\begin{array}{l}\text { How did this impact on learners' progress in the } \\
\text { lesson? }\end{array}$ & $\begin{array}{l}\text { How did this impact on learners' progress in the } \\
\text { lesson? Suggested improvements. }\end{array}$ \\
\hline
\end{tabular}


1. The learner-oriented interaction for learning helped my learners to personalise and feel responsible for their learning.

2. All learners were taking notes while listening, and this gave them a clear listening purpose, and prepared them well for reconstruction stage.
1. Learners could not get any feedback on the accuracy of their writing (Grammatical, word forms, etc) as I focused on the content. Need to include teaching element next time.

2. One group wrote manually, and other wrote electronically. I could retrieve and display the electronic copy easily for comparing, but the other group could not digitise their draft for open feedback. Need to instruct all learners type their answer next time.

\section{Suggestions for follow-up and consolidation}

I will continue this lesson in the following session focusing on the accuracy of their writing. I will ask them to compare their writing with the original one and identify any two tense issues/ differences. In addition, I will highlight wrong forms/ structures and encourage learners correct their mistakes without the help of the original text. Other areas of weakness will be addressed allotting enough time for teaching and giving clear instructions about typing their text at reconstruction stage.

\section{Appendix C. Learners' Feedback - Sample}

\begin{tabular}{|c|c|c|c|c|c|}
\hline How will you rate today's lesson? & & & & & \\
\hline Items & Strongly & Agree & Neutral & Disagree & Strongly \\
\hline & Agree & & & & Disagree \\
\hline $\begin{array}{l}\text { This lesson is good for meeting my learning } \\
\text { needs. }\end{array}$ & $\checkmark$ & & & & \\
\hline $\begin{array}{l}\text { This lesson helps me know strong and weak areas } \\
\text { of my learning (e.g...,, vocabulary, grammar, } \\
\text { speaking, etc.) }\end{array}$ & & $\checkmark$ & & & \\
\hline $\begin{array}{l}\text { I with my friends could successfully } \\
\text { reconstruct the text. }\end{array}$ & & $\checkmark$ & & & \\
\hline $\begin{array}{l}\text { This lesson enables me to work together with my } \\
\text { friends. }\end{array}$ & $\checkmark$ & & & & \\
\hline $\begin{array}{l}\text { This lesson integrated all four skills -- Listening, } \\
\text { speaking,, reading and writing }\end{array}$ & $\checkmark$ & & & & \\
\hline The lesson was well planned and implemented. & $\checkmark$ & & & & \\
\hline The listening audio was clear, and appropriate. & & $\checkmark$ & & & \\
\hline $\begin{array}{l}\text { I like to attend similar (dictogloss) lessons in } \\
\text { the future }\end{array}$ & $\checkmark$ & & & & \\
\hline
\end{tabular}


Choose one or more than one response.

\begin{tabular}{|c|c|c|c|c|c|}
\hline \multirow[t]{2}{*}{$\begin{array}{l}\text { I think lesson like this is most } \\
\text { helpful for improving students' }\end{array}$} & $\begin{array}{l}\text { Listening } \\
\text { Skill }\end{array}$ & Speaking Skill & Reading & Writing Skill & $\begin{array}{l}\text { Grammar \& } \\
\text { Vocabulary }\end{array}$ \\
\hline & $\checkmark$ & $\checkmark$ & & & \\
\hline
\end{tabular}

\begin{tabular}{l}
\hline The most interesting stage of the lesson was __ \\
\hline Dictation stage \\
\hline Reconstruction (writing the text with friends) \\
\hline The final stage of comparing and correcting the text. \\
\hline
\end{tabular}

\section{Write your overall impression and specific suggestions about today's lesson.}

Good for listening practice.

\section{Appendix D. Co-teachers' Feedback - Sample}

\begin{tabular}{|c|c|c|c|c|c|}
\hline How will you rate today's lesson & & & & & \\
\hline Items & Strongly & Agree & Neutral & Disagree & Strongly \\
\hline & Agree & & & & Disagree \\
\hline This lesson is good for meeting students' learning & & & & & \\
\hline needs. & $\checkmark$ & & & & \\
\hline This lesson helps students' know strong and weak & & $\checkmark$ & & & \\
\hline areas of their learning (e.g..., vocabulary, grammar, & & & & & \\
\hline speaking, etc.) & & & & & \\
\hline Students' with their friends could successfully & & $\checkmark$ & & & \\
\hline reconstruct the text. & & & & & \\
\hline This lesson enables students to work together with & $\checkmark$ & & & & \\
\hline their friends. & & & & & \\
\hline This lesson integrated all four skills -- Listening,, & $\checkmark$ & & & & \\
\hline speaking, reading and writing & & & & & \\
\hline The lesson was well planned and implemented & $\checkmark$ & & & & \\
\hline The listening audio was clear, and appropriate. & & $\checkmark$ & & & \\
\hline I like to attend/teach similar (dictogloss) lessons & $\checkmark$ & & & & \\
\hline in the future & & & & & \\
\hline
\end{tabular}




\section{Macrothink}

International Journal of Linguistics

ISSN 1948-5425

2022, Vol. 14, No. 1

Choose one or more than one response.

\begin{tabular}{|c|c|c|c|c|c|}
\hline \multirow[t]{2}{*}{$\begin{array}{l}\text { I think lesson like this is most helpful for } \\
\text { improving students' }\end{array}$} & $\begin{array}{c}\text { Listening } \\
\text { Skill }\end{array}$ & $\begin{array}{c}\text { Speaking } \\
\text { Skill }\end{array}$ & Reading & $\begin{array}{c}\text { Writing } \\
\text { Skill }\end{array}$ & $\begin{array}{l}\text { Grammar \& } \\
\text { Vocabulary }\end{array}$ \\
\hline & $\checkmark$ & $\checkmark$ & $\checkmark$ & $\checkmark$ & \\
\hline
\end{tabular}

The most interesting stage of the lesson was

\begin{tabular}{l}
\hline Dictation stage \\
\hline Reconstruction (writing the text with friends) \\
\hline The final stage of comparing and correcting the text. \\
\hline
\end{tabular}

\section{Write your overall impression and specific suggestions about today's lesson.}

I thought this was the most interesting and most successful lesson of yours I have seen yet!

The subject material was interesting and the learners were well engaged throughout.

I think for the writing stage you could have asked who is using a computer and asked them to share screen and write in microsoft word or some other word processor. The group that could compare on the screen had some very useful learning moments. The group seem to enjoy your teaching style and they get on with the work you set very well.

\section{Copyrights}

Copyright for this article is retained by the author(s), with first publication rights granted to the journal.

This is an open-access article distributed under the terms and conditions of the Creative Commons Attribution license (http://creativecommons.org/licenses/by/4.0/) 